\title{
Effect of Ruminally Protected Methionine on Splanchnic Metabolism of Amino Acids in Lactating Dairy Cows ${ }^{1}$
}

\author{
R. Berthiaume, ${ }^{\star 2}$ M. C. Thivierge,† R. A. Patton, $¥$ P. Dubreuil,§ M. Stevenson, $\|$ \\ B. W. McBride, $\rceil$ and H. Lapierre* \\ ${ }^{*}$ Agriculture and Agri-Food Canada, Lennoxville, QC, Canada J1M 1 Z3 \\ †Département des sciences animales, Université Laval, Ste-Foy, QC, Canada G1K 7P4 \\ $\ddagger$ Nittany Dairy Nutrition, Mifflinburg, PA 17844 \\ §Faculté de Médecine Vétérinaire, Université de Montréal, St-Hyacinthe, QC, Canada JZ5 3B7 \\ ||Degussa Canada Ltd., Burlington, ON, Canada L7R 3Y8 \\ qUniversity of Guelph, Guelph, ON, Canada NIG 2W1
}

\section{ABSTRACT}

The effect of ruminally protected Met (RPM) on splanchnic metabolism was measured in 3 primiparous and 3 multiparous Holstein cows. Doses of RPM $(0,36$, and $72 \mathrm{~g} / \mathrm{d})$ were tested in a replicated $3 \times 3$ Latin square design, over 3 consecutive 14-d experimental periods. A mixed ration was fed in 12 equal meals per d (average dry matter intake: $17.5 \pm 0.08 \mathrm{~kg} / \mathrm{d}$ ). Indwelling catheters were surgically implanted in the mesenteric artery and the portal and hepatic veins for blood collection, as well as in 2 distal branches of the mesenteric vein for infusion of $p$-aminohippurate to determine blood flow. On d 14 of each period, a temporary catheter was inserted into a mammary vein and 6 hourly blood samples were collected to determine plasma concentrations of metabolites, hormones, and their respective fluxes across the splanchnic bed and mammary glands. Yields of milk (32.8, 32.0, and 32.9 $\pm 0.92 \mathrm{~kg} / \mathrm{d})$ and protein $(1,028,1,053$, and $1,075 \pm 28.7$ $\mathrm{g} / \mathrm{d}$ ) were unaffected by level of RPM. However, the true protein content in milk from primiparous cows increased linearly $(2.92,3.09$, and $3.34 \pm 0.077 \%)$. The addition of RPM linearly increased the net flux of Met across the portal-drained viscera, which resulted in increased arterial Met concentrations (25, 29, and 40 $\pm 1.1 \mu M)$. Although it had no significant effect on net portal and hepatic fluxes of other essential amino acids, RPM resulted in a linear increase in the total splanchnic output of Ile, Leu, Phe, and Thr. These results suggest that feeding RPM triggered a homeostatic response resulting in less utilization of certain essential amino acids through the gastrointestinal tract and liver. Net mammary uptake of Met did not

Received February 25, 2005.

Accepted November 28, 2005

${ }^{1}$ Contribution no. 880 of the Dairy and Swine Research and Development Centre.

${ }^{2}$ Corresponding author: berthiaumer@agr.gc.ca change with the addition of RPM. However, mammary extraction of Met decreased in a linear fashion in response to increased arterial inflow.

Key words: methionine, amino acid, dairy cow, splanchnic

\section{INTRODUCTION}

Determining AA requirements and supply for lactating dairy cows is a challenge for nutritionists, although some progress has been made. A dose-response approach measuring lactational responses to graded levels of Met and Lys, either infused postruminally or fed in a rumen-protected form, combined with an estimation of AA flow to the duodenum, has been used to estimate Met and Lys requirements (Rulquin et al., 1995; Schwab, 1995). Despite the large number of assumptions underlying this approach, Met and Lys requirements are now included in a number of ration evaluation software (e.g., CPM Dairy, 1998; NRC, 2001; Amino Cow, 2004). However, to achieve a better understanding of the relation between supply of AA and milk protein output, more information is needed on postabsorptive metabolism of AA, including Met and its impact on the efficiency of conversion of absorbed AA into milk protein.

In series with the portal-drained viscera (PDV), the liver is the first organ to see newly absorbed AA and is a major site of catabolism for some essential AA, namely Met, His, Phe, and Thr (Lapierre et al., 2005). It is not clear, however, if this role is active or passive (Lobley and Lapierre, 2003), but it is clear that liver removal of AA is directly linked to total hepatic influx (Hanigan et al., 2004a). In early lactation dairy cows, hepatic removal of Met was shown to be substantial, varying between 30 and $40 \%$ of net portal absorption (Bach et al., 2000). In this study, fractional extraction rate of Met was not affected by the AA profile of dietary protein nor by the level of $\mathrm{CP}$, despite a significant increase $(51 \%)$ in net portal absorption. In contrast, 
Raggio et al. (2004) showed recently that hepatic removal of Met relative to net portal absorption linearly increased with increasing MP supply, going from $28 \%$ in the low MP diet to $44 \%$ in the high MP diet.

Unfortunately, none of these studies has investigated the behavior of hepatic extraction of AA in lactating dairy cows when the supply of a single AA is increased. Because Met is considered as one of the most limiting AA in many North American dairy cow diets, a trial was designed to establish the impact of using ruminally protected Met (RPM) to increase the supply of absorbable Met on portal delivery, hepatic removal, and mammary uptake of AA in relation with milk protein output in lactating dairy cows.

\section{MATERIALS AND METHODS}

\section{Animals and Treatments}

To measure the effect of RPM on splanchnic and mammary metabolism, 6 lactating ( 3 multiparous, and 3 primiparous) Holstein cows (BW: $596 \pm 12 \mathrm{~kg}$ ) averaging $76 \pm 1 \mathrm{DIM}$ at the beginning of the trial were used. Three doses $(0,36$, and $72 \mathrm{~g} / \mathrm{d}$ ) of RPM (Mepron M-85, Degussa Canada Ltd., Burlington, ON, Canada; 85.6\% Met on DM basis) added to the diet were evaluated in a replicated $3 \times 3$ Latin square design ( 1 square per parity group) balanced for residual effects (Gill, 1978 ), over 3 consecutive 14-d experimental periods. A mixed ration (Table 1) was divided in 12 equal meals per $d$ and fed every other hour. The amount of DM offered was reduced to $95 \%$ of average ad libitum DMI fed at the start of the experiment and then was held constant over the remainder of the study to minimize variation in DMI and maintain steady-state conditions. The mixed ration consisted of alfalfa-grass silage $(27 \%)$, corn silage $(26 \%)$, and a pelleted concentrate (47\%; on DM basis). In addition, $1 \mathrm{~kg}$ of grass hay was fed in one meal daily. Based on previous experiments, the long hay particles were provided to prevent digestive upset. Chemical composition of ingredients, mixed diet, and hay are summarized in Tables 2 and 3 . The control diet was formulated according to NRC (1989) and was estimated to supply $46 \mathrm{~g} / \mathrm{d}$ of Met and requirements were estimated to be $50 \mathrm{~g} / \mathrm{d}$ using the Mepron Dairy Ration Evaluator, Version 2.1 (1999).

At least 2 wk prior to the beginning of the trial, indwelling catheters were surgically implanted in the portal vein, one hepatic vein, and the caudal aorta via a mesenteric artery for blood collection. Additionally, two other catheters were positioned in distal branches of the mesenteric vein to allow infusion of $p$-aminohippurate (pAH) to determine blood flow (Huntington et al., 1989). A carotid artery was surgically elevated under the skin to provide an alternative source of arte-
Table 1. Ingredient composition of the diets for animals fed 3 levels of ruminally protected Met (RPM)

\begin{tabular}{|c|c|c|c|}
\hline \multirow[b]{2}{*}{ Ingredient ( $\mathrm{g} / \mathrm{kg}$ of $\mathrm{DM})$} & \multicolumn{3}{|c|}{ Treatments } \\
\hline & $\begin{array}{l}0 \mathrm{~g} / \mathrm{d} \\
\text { of RPM }\end{array}$ & $\begin{array}{l}36 \mathrm{~g} / \mathrm{d} \\
\text { of RPM }\end{array}$ & $\begin{array}{l}72 \mathrm{~g} / \mathrm{d} \\
\text { of RPM }\end{array}$ \\
\hline Grass-legume silage & 271 & 271 & 271 \\
\hline Corn silage & 257 & 257 & 257 \\
\hline Concentrate $^{1,2}$ & 472 & 472 & 472 \\
\hline \multicolumn{4}{|l|}{ Estimations from Amino Cow $(2004)^{2}$} \\
\hline \multicolumn{4}{|l|}{ Primiparous cows } \\
\hline $\mathrm{NE}_{\mathrm{L}}, \mathrm{Mcal} / \mathrm{d}$ & 27.1 & 26.9 & 27.1 \\
\hline $\operatorname{RDP}(\mathrm{g} / \mathrm{d})$ & 1,820 & 1,790 & 1,820 \\
\hline RUP (g/d) & 930 & 930 & 950 \\
\hline $\mathrm{MP}(\mathrm{g} / \mathrm{d})$ & 1,660 & 1,648 & 1,679 \\
\hline Met supplied (g/d) & 34 & 56 & 77 \\
\hline Met required (g/d) & 39 & 42 & 46 \\
\hline Lys supplied (g/d) & 126 & 123 & 124 \\
\hline Lys required (g/d) & 121 & 130 & 142 \\
\hline \multicolumn{4}{|l|}{ Multiparous cows } \\
\hline $\mathrm{NE}_{\mathrm{L}}, \mathrm{Mcal} / \mathrm{d}$ & 32.0 & 32.0 & 32.1 \\
\hline $\operatorname{RDP}(\mathrm{g} / \mathrm{d})$ & 2,180 & 2,190 & 2,200 \\
\hline RUP (g/d) & 1,110 & 1,140 & 1,160 \\
\hline $\mathrm{MP}(\mathrm{g} / \mathrm{d})$ & 2,027 & 2,010 & 2,027 \\
\hline Met supplied (g/d) & 41 & 63 & 84 \\
\hline Met required (g/d) & 51 & 50 & 51 \\
\hline Lys supplied (g/d) & 150 & 150 & 150 \\
\hline Lys required (g/d) & 156 & 151 & 154 \\
\hline
\end{tabular}

${ }^{1}$ Ingredients: ground shelled corn $(69.4 \%)$; soybean meal $(13.6 \%)$; soybean hulls (8.5\%); blood meal (4.2\%); mineral and vitamin mix $^{3}$ (2.3\%); dicalcium phosphate (1.5\%); binder (Lignosol, Tempec, Temiscaming, QC, Canada; 0.4\%); Limestone (0.06\%); $\mathrm{MgO}(0.004 \%)$.

${ }^{2}$ Composition: $\mathrm{CP}(2 \%)$; $\mathrm{NE}_{\mathrm{L}}(0.77 \mathrm{Mcal} / \mathrm{kg})$; Fat $(2.3 \%)$; $\mathrm{ADF}(1.5 \%)$; $\mathrm{Na}$ (15.6\%); Ca (15.3\%); P (0.1\%); $\mathrm{Mg}(3.5 \%) ; \mathrm{K}(0.087 \%) ; \mathrm{S}(1.1 \%) ;$ Co $(1,210 \mathrm{mg} / \mathrm{kg}) ; \mathrm{Mn}(4,060 \mathrm{mg} / \mathrm{kg}) ; \mathrm{Zn}(6,090 \mathrm{mg} / \mathrm{kg}) ; \mathrm{Cl}(24 \mathrm{mg} /$ $\mathrm{kg})$; Se $(24 \mathrm{mg} / \mathrm{kg}) ; \mathrm{Fe}(2,500 \mathrm{mg} / \mathrm{kg})$; Vitamin A (548,000 IU/kg); Vitamin D (185,000 IU/kg); Vitamin E (1,800 IU/kg).

${ }^{3}$ Calculated using intake and milk production reported in Tables 4 and 5 and chemical composition of ingredients reported in Tables 2 and 3 .

rial blood should the arterial catheter fail; this occurred for one cow. On d 14 of each period, a catheter was inserted in the mammary vein and secured so that it would remain in place during sampling. Animals were cared for according to the guidelines of the Canadian Council on Animal Care (1993) and the experimental protocol was approved by the Institutional Animal Care Committee.

\section{Sampling Procedure}

Experimental periods lasted 14 d. Feed samples were taken daily and composited for each period. On d 14 of each period, 6 hourly blood samples $(17 \mathrm{~mL}$ each) were simultaneously collected from the artery, and the portal, hepatic and mammary veins, starting at $0830 \mathrm{~h}$. Additional samples of arterial, portal, hepatic, and mammary blood $(2 \mathrm{~mL})$ were collected into a blood-gas collection device (Monovette, Sarstedt, Aktiegesellschaft and Co., Germany) for the determina- 
Table 2. Chemical composition of dietary ingredients

\begin{tabular}{lrrrr}
\hline & $\begin{array}{c}\text { Grass } \\
\text { silage }\end{array}$ & $\begin{array}{l}\text { Corn } \\
\text { silage }\end{array}$ & $\begin{array}{l}\text { Grass } \\
\text { hay }\end{array}$ & Concentrate \\
\hline DM, g/kg & 354 & 317 & 884 & 881 \\
OM, g/kg of DM & 898 & 956 & 927 & 932 \\
NDF, g/kg of DM & 371 & 539 & 650 & 136 \\
ADF, g/kg of DM & 299 & 315 & 354 & 74 \\
ADL, g/kg of NDF & 93 & 46 & 40 & 9 \\
Fat, g/kg of DM & 28 & 19 & 17 & 14 \\
NSC, g/kg of DM & 302 & 311 & 188 & 588 \\
Starch, g/kg of DM & 33 & 193 & 33 & 456 \\
CP, g/kg of DM & 228 & 103 & 117 & 202 \\
ADIN, \% of CP & 5 & 6 & 5 & 2 \\
NDIN, \% \% CP & 14 & 15 & 39 & 4 \\
Soluble N, \% of CP & 505 & 515 & 318 & 156 \\
NPN, g/kg of soluble N & 936 & 904 & 889 & 763 \\
Ca, g/kg of DM & 17 & 3 & 4 & 11 \\
P, g/kg of DM & 3 & 3 & 4 & 9 \\
Mg, g/kg of DM & 3 & 2 & 2 & 3 \\
K, g/kg of DM & 21 & 12 & 27 & 9 \\
\hline
\end{tabular}

${ }^{1} \mathrm{ADL}=$ Acid detergent lignin.

${ }^{2} \mathrm{NSC}$ (nonstructural carbohydrates) $=100-\mathrm{CP}-(\mathrm{NDF}-\mathrm{NDIN})$ - Fat - Ash.

${ }^{3} \mathrm{NDIN}=$ Neutral detergent insoluble nitrogen.

tion of $\mathrm{pH}$ and concentrations of $\mathrm{O}_{2}$ and $\mathrm{CO}_{2}$. Blood flow in the portal and hepatic vein was determined by downstream dilution of pAH (10\% wt/vol) infused continuously $(144 \mathrm{~mL} / \mathrm{h})$ into one distal mesenteric vein catheter. This followed a priming dose of $20 \mathrm{~mL}$ started at least $40 \mathrm{~min}$ before the first sample collection. Immediately after collection, aprotinin (500 trypsin inhibitor units $/ \mathrm{mL}$ ) was added to a $2-\mathrm{mL}$ aliquot of blood for glucagon analysis. Blood samples were kept on ice until processed (usually within $1 \mathrm{~h}$ ).

\section{Laboratory Analysis}

Samples of feed were lyophilized and ground to pass a $1-\mathrm{mm}$ screen. Subsamples of feed were ashed at

Table 3. Amino acid composition of dietary ingredients

\begin{tabular}{lcllr}
\hline $\begin{array}{l}\text { AA, g/kg } \\
\text { of DM }\end{array}$ & $\begin{array}{l}\text { Grass } \\
\text { silage }\end{array}$ & $\begin{array}{l}\text { Corn } \\
\text { silage }\end{array}$ & $\begin{array}{l}\text { Grass } \\
\text { hay }\end{array}$ & Concentrate \\
\hline Arg & 6.3 & 2.1 & 4.7 & 11.2 \\
His & 3.3 & 1.3 & 1.7 & 6.1 \\
Ile & 8.4 & 3.4 & 4.0 & 6.2 \\
Leu & 14.3 & 7.5 & 7.6 & 12.9 \\
Lys & 8.8 & 2.2 & 4.7 & 10.6 \\
Met & 3.1 & 1.5 & 1.7 & 2.6 \\
Phe & 8.6 & 3.5 & 4.9 & 9.0 \\
Thr & 8.4 & 3.1 & 4.4 & 6.7 \\
Val & 12.7 & 4.3 & 5.9 & 10.6 \\
Ala & 12.1 & 6.4 & 6.5 & 12.1 \\
Asp & 2.0 & 6.2 & 9.1 & 18.6 \\
Glu & 16.0 & 9.2 & 9.9 & 30.5 \\
Gly & 9.6 & 3.7 & 5.1 & 8.2 \\
Pro & 9.8 & 5.2 & 5.7 & 11.6 \\
Ser & 9.0 & 3.8 & 4.3 & 9.7 \\
Cys & 1.8 & 1.3 & 1.2 & 3.2 \\
\hline
\end{tabular}

$550^{\circ} \mathrm{C}$ for $12 \mathrm{~h}$ in a muffle furnace. Feed $\mathrm{N}$ was determined by micro-Kjeldahl analysis (AOAC, 1996) and $\mathrm{N}$ in milk was determined by thermal conductivity (Leco model FP-428 Nitrogen Determinator, Leco, St. Joseph, MI). Crude protein contents of feed and milk were calculated as $\mathrm{N} \times 6.25$ and $\mathrm{N} \times 6.38$, respectively. Noncasein N and NPN in milk were analyzed with the micro-Kjeldahl method. Noncasein $\mathrm{N}$ was obtained by precipitation of the caseins at $\mathrm{pH}$ 4.6. Nonprotein $\mathrm{N}$ was obtained by precipitation with TCA, at a final concentration of $12 \%$. Casein $\mathrm{N}$ was calculated by the difference between total $\mathrm{N}$ and noncasein $\mathrm{N}$, and whey protein was estimated by difference between noncasein $\mathrm{N}$ and NPN. Milk fat was measured according to the Röse-Gottlieb method (AOAC, 1996). Milk samples were analyzed for DM and OM with a thermogravimetric analyzer (Model TGA 601, Leco) and milk lactose was determined by difference (DM - Ash - CP - Fat). Fiber fractions (NDF, ADF, and lignin), ADIN, and neutral detergent insoluble $\mathrm{N}$ were determined on feed samples according to Van Soest et al. (1991). Feeds were analyzed for $\mathrm{pH}$, soluble $\mathrm{N}$, and NPN according to Krishnamoorthy et al. (1983). For AA determination, samples of feed were predigested with performic acid to stabilize Met and Cys, treated with hydrobromic acid to destroy the performic acid, and then acid-hydrolyzed with $6 \mathrm{~N} \mathrm{HCl}$ (method \# 994-12; AOAC, 1996). A separate acid hydrolysis $(6 \mathrm{~N} \mathrm{HCl})$ digestion procedure was conducted for Phe, Tyr, and His, because those AA are destroyed during the oxidation process and by reaction with bromine. Concentrations of AA were quantified by ion exchange chromatography (Beckmann 6300, Beckmann Instruments, Palo Alto, $\mathrm{Ca})$.

Measurements of blood packed-cell volume, partial pressure of $\mathrm{O}_{2}$ and $\mathrm{CO}_{2}$, and $\mathrm{pH}$ were obtained immediately after collection using a blood gas analyzer (Model IL 1306, Instrumentation Laboratory, Lexington, MA). The packed cell volume of each blood sample was determined by the microhematocrit method (Strumia et al., 1954). Hemoglobin was determined colorimetrically using cyanmethemoglobin as the standard. Concentrations of blood urea, pAH, ammonia- $\mathrm{N}$ and $\alpha-$ amino-N, and plasma pAH were determined using the Technicon AutoAnalyzer on the day of sampling except for plasma $\mathrm{pAH}$, which was frozen and analyzed later (Huntington, 1984). The ammonia-N concentrations were corrected for an $\alpha$-amino-N reaction in the ammonia assay, using the relative response of a leucine standard and measured $\alpha$-amino-N concentrations (Broderick and Kang, 1980). An enzymatic method (Kit \#166391, Boehringer Mannheim, Dorval, QC, Canada) was used to determine plasma glucose. For glucagon analysis, samples with aprotinin were centrifuged at 
$2,100 \times g$ for 12 min and plasma samples were kept frozen until analyzed. Plasma hormone concentrations were determined using double-antibody radioimmunoassay as described by Lapierre et al. (1992) for insulin and by Herbein et al. (1985) for glucagon (30 K antibodies, Univ. Texas, Southwestern Medical School, Dallas, TX). Inter- and intraassay coefficients of variation for insulin were 6.6 and $13.2 \%$, and for glucagon were 9.1 , and $6.4 \%$, respectively. Blood AA were determined by two methods. The essential AA His, Ile, Leu, Lys, Met, Phe, Thr, and Val, and two nonessential AA-Cys, which is involved in the metabolism of Met, and Tyr, which was used to estimate mammary blood flow according to the Fick principlewere analyzed on whole blood by isotopic dilution (Calder et al., 1999). This technique was chosen because results are less variable than results obtained with AA analyzers. For this method, $1.5 \mathrm{~mL}$ of an internal standard solution of AA was added to $1.5 \mathrm{~mL}$ of whole blood and immediately frozen until analyzed by isotopic dilution with a gas chromatograph coupled to a mass spectrometer (GC-MS, Hewlett Packard, Houston, TX; GC: model HP6890; MS: S973). The internal standard solution was prepared with labeled AA diluted in $0.1 \mathrm{~N} \mathrm{HCl}$ to give the following concentration $(\mu M)$ : L-Cys- ${ }^{15} \mathrm{~N}$ (40), DL-His- $\alpha-{ }^{15} \mathrm{~N}$ (34.6), L-Ile- ${ }^{15} \mathrm{~N}$ (142.6), L-Leu-1- ${ }^{13} \mathrm{C}$ (175.4), DL-Lys- $2{ }^{15} \mathrm{~N}-2 \mathrm{HCl}$ (67.1), DL-Met- $1-{ }^{13} \mathrm{C}$ (19.6), L-Phe- $1-{ }^{13} \mathrm{C}$ (45.1), L-Thr $-{ }^{15} \mathrm{~N}$ (9.1), L-Tyr $-{ }^{15} \mathrm{~N}$ (53.1), and $\mathrm{L}-\mathrm{Val}-{ }^{15} \mathrm{~N}$ (169.2). The labeled AA, His, Leu, Lys, Met, and Phe (95 to 99 atom $\%$ ) were supplied by CDN Isotopes (Pointe-Claire, QC, Canada); Cys, Ile, Thr, and Tyr by Cambridge Isotope Laboratories (Andover, MA), and Val by Isotec, Inc. (Miamisburg, OH). Analysis was performed on each of the 6 hourly samples.

All AA were also determined in plasma. For this method, the 6 hourly samples were pooled for every 2 -h sampling period into 3 pooled samples. Then, 200 $\mathrm{mg}$ of a dithiothreitol $(5 \mathrm{~m} M)$-norleucine $(1 \mathrm{mM})$ solution was added to $1 \mathrm{~g}$ of plasma and vortexed. This mixture was deproteinized by adding $150 \mu \mathrm{L}$ of sulfosalicylic acid (48\%), and then centrifuged at 16,610 $\times g$ for $12 \mathrm{~min}$. The supernatant was decanted and centrifuged as described above. The $\mathrm{pH}$ of the filtrate was adjusted to 2.0 to 2.5 with 20 to $50 \mu \mathrm{L}$ of $\mathrm{NaOH}$ (10\%) and kept frozen. Samples were analyzed for individual free AA using an amino acid analyzer (Pharmacia Alpha Plus II; Amersham Pharmacia Biotech, Little Chalfont, UK). Due to technical problems with His analyses on whole blood samples, plasma values are reported. Therefore, reported concentrations of Ile, Leu, Lys, Met, Phe, Thr, Val, Cys, and Tyr were based on whole blood samples ( $\mathrm{n}=6$ per day of sampling) and concentrations of other AA reported were based on plasma samples ( $\mathrm{n}=3$ per day of sampling).

\section{Calculations and Statistical Analyses}

Blood and plasma flows in the portal and hepatic veins were measured by dilution of $\mathrm{pAH}$ (Katz and Bergman, 1969). Within one sampling day, if the CV of the mean plasma flow for an animal was greater than $15 \%$ due to only one sample, this value was removed. Milk protein output was estimated using milk protein yield and the AA composition of milk protein reported by Swaisgood (1995). Mammary plasma flow was estimated according to the Fick principle, using Phe and Tyr as internal markers (Mepham, 1982), with allowance for a 3.5\% contribution from bloodborne proteins \{mammary plasma flow $=[$ (milk Phe + Tyr $) \times 0.965 /($ arterial-venous difference of Phe + Tyr $)]\}$ (Cant et al., 1993). Concentrations of $\mathrm{O}_{2}$ in blood were calculated using measured partial pressures of $\mathrm{O}_{2}, \mathrm{pH}$, and hemoglobin concentrations according to Bartels and Harms (1959), whereas concentrations of $\mathrm{CO}_{2}$ in plasma were calculated using partial pressure of $\mathrm{CO}_{2}$ and $\mathrm{pH}$ (Oddy et al., 1984). Daily net fluxes were calculated as the product of blood or plasma flow and blood or plasma venous-arterial (VA) difference for the PDV, liver, the whole splanchnic bed (TSP), and the mammary glands (MG). Negative fluxes denote a net removal of a metabolite or hormone by the tissue whereas positive fluxes denote a net release from the tissue. Essential amino acids (EAA) evaluated were His, Ile, Leu, Lys, Met, Phe, Thr, and Val; nonessential amino acids (NEAA) were Ala, Arg, Asn, Asp, Cys, Glu, Gly, Pro, Ser, and Tyr; and branched-chain amino acids (BCAA) were Ile, Leu, and Val. Total amino acids were the sum of EAA and NEAA.

The VA differences (hepatic vein - arterial, portal vein - arterial, hepatic vein - portal vein, and mammary vein - arterial) were tested for difference from zero using the Student's $t$-test. Daily means of arterial concentrations, VA differences, and net fluxes were calculated for each cow in each experimental period. All data were analyzed according to a replicated Latin square design balanced for residual effects using the Mixed procedure of SAS (SAS Institute, 2000), with square, cow (square), period, treatment, and the interaction parity by treatment all as fixed effects. The linear and quadratic effects of treatment were tested with polynomial contrasts (Gill, 1978). Treatment differences were considered significant if $P<0.10$ unless otherwise stated.

Initial inspection of the milk composition data revealed that, there was an interaction $(P<0.05)$ between parity and treatment. Also, the same interaction 
Table 4. Effect of increasing levels of ruminally protected Met (RPM) on milk production and composition of primiparous cows ${ }^{1}$

\begin{tabular}{|c|c|c|c|c|c|c|}
\hline \multirow[b]{2}{*}{ Item } & \multicolumn{3}{|c|}{ RPM level, g/d } & \multirow[b]{2}{*}{ SEM } & \multicolumn{2}{|c|}{$P$} \\
\hline & 0 & 36 & 72 & & Linear & Quadratic \\
\hline DMI, kg/d & 15.9 & 15.7 & 15.9 & 0.12 & 0.87 & 0.52 \\
\hline Weight change, kg & 7.3 & -0.3 & -9.4 & 9.3 & 0.22 & 0.91 \\
\hline Milk, kg/d & 27.7 & 28.4 & 29.4 & 2.29 & 0.42 & 0.91 \\
\hline $\mathrm{CP}, \%$ & 3.07 & 3.23 & 3.49 & 0.08 & 0.04 & 0.65 \\
\hline $\mathrm{CP}, \mathrm{g} / \mathrm{d}$ & 849 & 919 & 1,024 & 72.3 & 0.11 & 0.79 \\
\hline True N, \% & 0.457 & 0.484 & 0.523 & 0.012 & 0.05 & 0.65 \\
\hline True N, g/d & 126 & 137 & 154 & 10.9 & 0.11 & 0.78 \\
\hline Casein N, \% & 0.307 & 0.326 & 0.387 & 0.015 & 0.07 & 0.38 \\
\hline Casein N, g/d & 85 & 93 & 114 & 9.0 & 0.11 & 0.60 \\
\hline Fat, $\%$ & 3.41 & 3.10 & 3.06 & 0.11 & 0.16 & 0.41 \\
\hline Fat, g/d & 945 & 872 & 899 & 61.1 & 0.38 & 0.29 \\
\hline Lactose, \% & 5.17 & 5.29 & 4.95 & 0.186 & 0.30 & 0.24 \\
\hline Lactose, $\mathrm{g} / \mathrm{d}$ & 1,424 & 1,494 & 1,453 & 91.3 & 0.72 & 0.47 \\
\hline
\end{tabular}

${ }^{1}$ Least squares means with SEM given for $\mathrm{n}=3$.

was found for arterial concentrations of taurine (Tau) and net hepatic fluxes of Glu, Gly, and Val. There is inherent variation to be considered in this study associated with the measurement of net fluxes, the very large number of metabolites analyzed, and the associated probability of "detecting" significance when there was in fact none (Type 2 error). Therefore, it was decided to analyze and report the milk production and blood flow data for each parity group separately, noting the limited number of cases where there was a significant interaction on blood metabolites. Except for milk production and composition data, analyzing data separately had no effect on the biological interpretation.

\section{RESULTS}

One multiparous animal (cow \#449) did not have a functional portal catheter in periods 1 and 2 . Therefore, $\mathrm{n}=6$ per treatment of TSP data and $\mathrm{n}=5,6$, and 5 for treatment 0,36 , and $72 \mathrm{~g} / \mathrm{d}$ of RPM, for PDV and liver values. Another primiparous cow (\#603) lost its mammary catheter in period 3 . Therefore, $\mathrm{n}=6$, 5 , and 6 for the 0,36 , and $72 \mathrm{~g} / \mathrm{d}$ RPM treatments, for mammary data.

\section{Milk Production and Composition}

As previously discussed, milk production and composition, and blood and plasma flow data were analyzed and reported separately for primiparous and multiparous cows because of a significant interaction between parity and treatment. Graded levels of RPM had no effect on DMI and milk production (Tables 4 and 5). However, in primiparous cows (Table 4), milk CP percentage $(P=0.04)$, true $\mathrm{N}$ percentage $(P=0.05)$, and casein $\mathrm{N}$ percentage $(P=0.07)$ increased linearly with increasing levels of RPM. Conversely, in multiparous cows (Table 5), RPM had no effect on milk composition. Blood and plasma flows through the PDV and MG were unaffected by treatments (Table 6). However, for TSP blood and plasma flows, an interaction $(P<0.05)$ existed between the parity and the treatments. Ruminally protected Met caused a linear increase in blood $(P=0.09)$ and plasma flow $(P=0.07)$ across the TSP in the multiparous cows, but not in primiparous cows.

\section{Amino Acids}

Arterial concentrations of individual AA are presented in Table 7. Arterial Met increased slightly with the $36 \mathrm{~g} / \mathrm{d}$ level of RPM intake compared with the control, but increased sharply on the $72 \mathrm{~g} / \mathrm{d}$ level (linear effect, $P<0.001$; quadratic effect, $P=0.05$ ). Arterial Gln actually declined for the $36 \mathrm{~g} / \mathrm{d}$ level compared with control but was highest at the $72 \mathrm{~g} / \mathrm{d}$ level (linear effect, $P=0.07$; quadratic effect, $P=0.02$ ). Concentrations of Cys and Tau $(P<0.07)$ increased linearly with RPM, and concentrations of Leu, Val, and Phe $(P<$ $0.10)$ decreased linearly. Supplementation with RPM had a quadratic effect on arterial concentrations of Ala, Asn, and Ser $(P<0.10)$. All 3 AA decreased on the $36 \mathrm{~g} / \mathrm{d}$ level of RPM intake but returned to control levels on $72 \mathrm{~g} / \mathrm{d}$ of RPM. A significant parity $\times$ treatment interaction existed for Tau. For multiparous cows, the addition of RPM elicited a quadratic effect on the arterial concentration of Tau with a maximum reached at $36 \mathrm{~g} / \mathrm{d}$ of RPM, whereas for primiparous cows, the quadratic response was reversed with arterial concentration of Tau decreasing to a minimum after the addition of $36 \mathrm{~g} / \mathrm{d}$ of RPM.

The VA differences for most AA were different from zero (data not shown). Exceptions were Cys, Gln, and Tau (portal - arterial differences); the BCAA, Cys, 
Table 5. Effect of increasing levels of ruminally protected Met (RPM) on milk production and composition of multiparous cows ${ }^{1}$

\begin{tabular}{|c|c|c|c|c|c|c|}
\hline \multirow[b]{2}{*}{ Item } & \multicolumn{3}{|c|}{ RPM, g/d } & \multirow[b]{2}{*}{ SEM } & \multicolumn{2}{|c|}{$P$} \\
\hline & 0 & 36 & 72 & & Linear & Quadratic \\
\hline DMI, kg/d & 19.0 & 19.1 & 19.1 & 0.12 & 0.87 & 0.52 \\
\hline Weight change, kg & -5.7 & 8.7 & -3.7 & 4.2 & 0.74 & 0.10 \\
\hline Milk, kg/d & 37.4 & 36.0 & 37.1 & 3.15 & 0.88 & 0.56 \\
\hline $\mathrm{CP}, \%$ & 3.21 & 3.22 & 3.18 & 0.03 & 0.73 & 0.73 \\
\hline $\mathrm{CP}, \mathrm{g} / \mathrm{d}$ & 1197 & 1154 & 1163 & 57.20 & 0.69 & 0.72 \\
\hline True N, \% & 0.477 & 0.479 & 0.472 & 0.026 & 0.79 & 0.77 \\
\hline True N, g/d & 178 & 171 & 173 & 8.42 & 0.70 & 0.74 \\
\hline Casein N, \% & 0.329 & 0.324 & 0.324 & 0.025 & 0.76 & 0.82 \\
\hline Casein N, g/d & 123 & 116 & 120 & 10.86 & 0.82 & 0.61 \\
\hline Fat, \% & 3.34 & 3.46 & 3.54 & 0.20 & 0.12 & 0.73 \\
\hline Fat, g/d & 1244 & 1245 & 1313 & 117.6 & 0.53 & 0.72 \\
\hline Lactose, \% & 4.80 & 4.78 & 4.87 & 0.218 & 0.75 & 0.78 \\
\hline Lactose, $\mathrm{g} / \mathrm{d}$ & 1,783 & 1,718 & 1,783 & 84.0 & 0.99 & 0.25 \\
\hline
\end{tabular}

${ }^{1}$ Least squares means with SEM given for $\mathrm{n}=3$.

Lys, Asp, Arg, Gln, Pro, and Tau (hepatic - portal differences); Gln, Pro, and Tau (hepatic - arterial differences); and Cys, Gly, Pro, and Tau (mammary arterial differences).

Net fluxes of individual AA across the PDV, liver, TSP, MG, and in milk are presented in Table 8. The addition of RPM to the diet linearly increased PDV flux of Met $(P=0.10)$ and Gly $(P=0.08)$. The PDV net fluxes of Glu $(P=0.09)$ responded quadratically to RPM supplementation, being highest for the $36 \mathrm{~g} / \mathrm{d}$ level of intake. Hepatic removal of $\operatorname{Arg}(P=0.10)$ and liver release of $\mathrm{Val}(P=0.07)$ were affected quadratically by RPM. Liver removal of Asn $(P=0.03)$ linearly increased with the addition of RPM. Addition of RPM had both a linear $(P=0.03)$ and quadratic $(P=0.06)$ effect on the net hepatic flux of Gly. Net fluxes across the TSP of Ala, Ile, Leu, Phe, Thr, and Tyr $(P<0.10)$ all increased linearly with increasing RPM. Additionally there was a strong quadratic effect on Thr $(P<.001)$ with the $36 \mathrm{~g} / \mathrm{d}$ level showing the lowest TSP release. The net TSP flux of Asp $(P=0.006)$ responded in a quadratic fashion similar to Thr. Across the MG, RPM caused a linear increase in the uptake of His $(P=0.08)$ and a quadratic response in the uptake of Asp, Ile, $\mathrm{Leu}$, and $\mathrm{Val}(P \leq 0.09)$. For the latter $4 \mathrm{AA}$, the response was always a higher uptake for the $36 \mathrm{~g} / \mathrm{d}$ compared with control and $72 \mathrm{~g} / \mathrm{d}$ levels. The RPM had both a linear $(P=0.002)$ and quadratic $(P=0.05)$ effect on mammary uptake of Ala and Glu. Extraction of Ala was increased on $72 \mathrm{~g} / \mathrm{d}$ but was unaffected by the 36 g/d of RPM; Glu uptake, on the other hand, was highest at $36 \mathrm{~g} / \mathrm{d}$ and lowest at $72 \mathrm{~g} / \mathrm{d}$.

Table 6. Effect of graded amounts of ruminally protected Met (RPM) on splanchnic blood and plasma flows $(\mathrm{l} / \mathrm{h})$ in lactating Holstein cows ${ }^{1}$

\begin{tabular}{|c|c|c|c|c|c|c|c|}
\hline \multirow[b]{2}{*}{ Tissue $^{2}$} & & \multicolumn{3}{|c|}{ RPM, g/d } & \multirow[b]{2}{*}{ SEM } & \multicolumn{2}{|c|}{$P$} \\
\hline & & 0 & 36 & 72 & & Linear & Quadratic \\
\hline \multicolumn{8}{|c|}{ Primiparous } \\
\hline \multirow[t]{3}{*}{ Blood } & PDV & 1,759 & 1,722 & 1,775 & 109.6 & 0.87 & 0.60 \\
\hline & TSP & 2,222 & 2,070 & 2,055 & 84.0 & 0.18 & 0.44 \\
\hline & MG & 736 & 864 & 678 & 87.3 & 0.67 & 0.36 \\
\hline \multirow[t]{3}{*}{ Plasma } & PDV & 1,254 & 1,223 & 1,266 & 73.0 & 0.90 & 0.65 \\
\hline & TSP & 1,569 & 1,472 & 1,461 & 71.5 & 0.26 & 0.55 \\
\hline & MG & 586 & 674 & 490 & 75.8 & 0.43 & 0.33 \\
\hline \multicolumn{8}{|c|}{ Multiparous } \\
\hline \multirow[t]{3}{*}{ Blood } & PDV & 2,190 & 2,212 & 2,271 & 225.9 & 0.83 & 0.95 \\
\hline & TSP & 2,446 & 2,632 & 2,778 & 137.5 & 0.09 & 0.85 \\
\hline & MG & 1,087 & 1,095 & 993 & 86.6 & 0.28 & 0.43 \\
\hline \multirow{3}{*}{ Plasma } & PDV & 1,566 & 1,606 & 1,624 & 163.3 & 0.83 & 0.96 \\
\hline & TSP & 1,746 & 1,918 & 1,992 & 107.5 & 0.07 & 0.49 \\
\hline & MG & 821 & 816 & 757 & 110.4 & 0.36 & 0.62 \\
\hline
\end{tabular}

${ }^{1}$ Least squares means with SEM given for $\mathrm{n}=5 ; \mathrm{n}=5,6$, and 5 with 0,36 , and $72 \mathrm{~g} / \mathrm{d}$ of RPM, respectively, for PDV data; $\mathrm{n}=6$ for TSP data; $\mathrm{n}=6,5$, and 6 with 0,36 , and $72 \mathrm{~g} / \mathrm{d}$ of RPM, respectively, for MG data.

${ }^{2}$ Tissues: $\mathrm{PDV}=$ portal-drained viscera; TSP $=$ total splanchnic; $\mathrm{MG}=$ mammary glands. 
Table 7. Effect of graded amounts of ruminally protected Met (RPM) on arterial concentrations of AA $(\mu M)$ in lactating Holstein cows ${ }^{1}$

\begin{tabular}{|c|c|c|c|c|c|c|}
\hline \multirow[b]{2}{*}{ AA } & \multicolumn{3}{|c|}{ RPM, g/d } & \multirow[b]{2}{*}{ SEM } & \multicolumn{2}{|c|}{$P$} \\
\hline & 0 & 36 & 72 & & Linear & Quadratic \\
\hline Ala & 220 & 196 & 245 & 11.2 & 0.17 & 0.04 \\
\hline Arg & 73 & 65 & 75 & 4.6 & 0.73 & 0.14 \\
\hline Asn & 33 & 27 & 32 & 1.8 & 0.94 & 0.06 \\
\hline Asp & 6.4 & 6.2 & 6.3 & 0.3 & 0.93 & 0.69 \\
\hline $\mathrm{Cys}^{2}$ & 108 & 112 & 114 & 1.8 & 0.04 & 0.78 \\
\hline Gln & 204 & 195 & 218 & 4.3 & 0.07 & 0.02 \\
\hline Glu & 46 & 43 & 43 & 1.6 & 0.29 & 0.41 \\
\hline Gly & 268 & 243 & 255 & 11.1 & 0.42 & 0.23 \\
\hline His & 75 & 70 & 76 & 3.9 & 0.81 & 0.25 \\
\hline $\mathrm{Ile}^{2}$ & 103 & 93 & 94 & 3.4 & 0.11 & 0.22 \\
\hline $\mathrm{Leu}^{2}$ & 238 & 215 & 214 & 8.1 & 0.08 & 0.28 \\
\hline Lys $^{2}$ & 98 & 96 & 103 & 2.7 & 0.27 & 0.24 \\
\hline Met $^{2}$ & 25 & 29 & 40 & 1.1 & $<0.001$ & 0.05 \\
\hline $\mathrm{Phe}^{2}$ & 60 & 57 & 56 & 1.1 & 0.09 & 0.63 \\
\hline Pro & 97 & 90 & 105 & 9.9 & 0.60 & 0.40 \\
\hline Ser & 91 & 78 & 87 & 4.7 & 0.51 & 0.10 \\
\hline Taurine $^{3}$ & 28 & 28 & 32 & 1.4 & 0.07 & 0.29 \\
\hline $\mathrm{Thr}^{2}$ & 98 & 89 & 100 & 4.5 & 0.81 & 0.13 \\
\hline $\mathrm{Tyr}^{2}$ & 61 & 59 & 58 & 1.4 & 0.18 & 0.74 \\
\hline $\mathrm{Val}^{2}$ & 281 & 258 & 250 & 10.4 & 0.08 & 0.59 \\
\hline
\end{tabular}

${ }^{1}$ Least squares means with SEM, $\mathrm{n}=6$.

${ }^{2}$ Measured on whole blood ( $\mathrm{n}=6$ hourly samples).

${ }^{3}$ Parity $\times$ treatment interaction $(P=0.04)$.

\section{Metabolites and Hormones}

Blood $\mathrm{pH}(7.43 \pm 0.003)$, packed-cell volume (28.43 $\pm 0.22 \%)$, hemoglobin $(9.34 \pm 0.07 \mathrm{~g} / \mathrm{dL})$, and $\mathrm{O}_{2}(5.61$ $\pm 0.04 \mathrm{mM})$ and $\mathrm{CO}_{2}(27.70 \pm 0.13 \mathrm{mM})$ content were not affected by RPM. Arterial concentrations of various metabolites and hormones are presented in Table 10. There were no effects of RPM on arterial concentrations of ammonia-N, urea-N, glucose, glucagon, or insulin. The VA differences for all metabolites were different from zero (data not shown), except for glucose (portal - arterial differences), and ammonia-N (hepatic-arterial differences). There were no effects of RPM on PDV and TSP fluxes of the same metabolites and hormones (Table 10).

\section{DISCUSSION}

\section{Milk Production and Composition}

Milk production and composition were affected differently by RPM when fed to primiparous compared with multiparous cows. During the course of our study, a similar interaction was reported based on commercial farm trials in which the same source of RPM was fed (Patton et al., 1998). Assessing which dietary factors correlated most with milk yield response, the authors concluded that, other than metabolizable Met, metabolizable Lys accounted for the majority of the variation in milk yield (Patton et al., 1998; Peel and
Patton, 1998). Evaluation of the diet in the current study with AminoCow (2004) predicted a Met deficiency for both parities, but a Lys deficiency for the multiparous cows only (Table 1 ).

\section{Blood Flow}

Blood $\mathrm{pH}$, hemoglobin, and packed-cell volume were in the normal range for lactating dairy cows and were not affected by RPM. The significant interaction between parity and treatment on TSP flows remains unexplained but could merely be due to the difference in DMI (15 vs. $19 \mathrm{~kg} / \mathrm{d}$ ) observed between primiparous and multiparous cows. Average portal $(1,420 \mathrm{~L} / \mathrm{h})$, splanchnic $(1,693 \mathrm{~L} / \mathrm{h})$, and mammary $(697 \mathrm{~L} / \mathrm{h})$ plasma flows observed in this study are in the range reported in recent studies with lactating dairy cows in different stages of lactation and fed different diets (Bach et al., 2000; Benson et al., 2002; Blouin et al., 2002; Reynolds et al., 2003; Raggio et al., 2004). In these reports, portal plasma flows ranged from 1,193 to $1,807 \mathrm{~L} / \mathrm{h}$ and splanchnic flows from 1,419 to 2,272 L/h. Moreover, portal blood flow made up $84 \%$ of splanchnic blood flow, which is in close agreement with the above studies. In the case of mammary plasma flow, our data are in good agreement with that of other groups using the Fick principle with Phe and Tyr as marker AA. A review of recently published data (Vanhatalo et al., 1999; Varvikko et al., 1999; Bach et al., 
BERTHIAUME ET AL.

Table 8. Effect of graded amounts of ruminally protected Met (RPM) on splanchnic and mammary net fluxes of $\mathrm{AA}(\mathrm{mmol} / \mathrm{h})$ in lactating Holstein $\operatorname{cows}^{1}$

\begin{tabular}{|c|c|c|c|c|c|c|c|}
\hline \multirow[b]{2}{*}{ Amino acid } & \multirow[b]{2}{*}{ Tissue $^{2}$} & \multicolumn{3}{|c|}{ RPM, g/d } & \multirow[b]{2}{*}{ SEM } & \multicolumn{2}{|c|}{$P$} \\
\hline & & 0 & 36 & 72 & & Linear & Quadratic \\
\hline \multirow[t]{5}{*}{ Ala } & PDV & 57.7 & 68.7 & 71.0 & 7.9 & 0.25 & 0.62 \\
\hline & Liver & -31.8 & -39.8 & -40.3 & 5.3 & 0.27 & 0.53 \\
\hline & TSP & 25.9 & 28.9 & 35.9 & 3.7 & 0.10 & 0.68 \\
\hline & $\mathrm{MG}$ & -15.2 & -15.3 & -23.7 & 1.5 & 0.002 & 0.05 \\
\hline & Milk & 15.2 & 16.0 & 15.9 & 0.62 & 0.39 & 0.49 \\
\hline \multirow[t]{5}{*}{ Arg } & PDV & 23.9 & 24.9 & 24.0 & 2.4 & 0.96 & 0.72 \\
\hline & Liver & -2.1 & -4.3 & -1.9 & 1.1 & 0.89 & 0.10 \\
\hline & TSP & 21.8 & 18.9 & 21.0 & 1.5 & 0.71 & 0.21 \\
\hline & $\mathrm{MG}$ & -23.1 & -24.5 & -23.3 & 1.5 & 0.92 & 0.47 \\
\hline & Milk & 8.0 & 8.4 & 8.4 & 0.3 & 0.39 & 0.49 \\
\hline \multirow[t]{5}{*}{ Asn } & PDV & 16.9 & 17.0 & 20.8 & 2.2 & 0.21 & 0.46 \\
\hline & Liver & -6.6 & -7.9 & -11.1 & 1.1 & 0.03 & 0.45 \\
\hline & TSP & 10.3 & 9.2 & 10.5 & 1.2 & 0.89 & 0.44 \\
\hline & MG & -6.0 & -6.1 & -6.4 & 0.3 & 0.37 & 0.85 \\
\hline & Milk & 13.0 & 13.7 & 13.6 & 0.53 & 0.39 & 0.49 \\
\hline \multirow[t]{5}{*}{ Asp } & PDV & 6.5 & 3.9 & 4.6 & 1.9 & 0.47 & 0.44 \\
\hline & Liver & 0 & 0 & 1.9 & 2.1 & 0.50 & 0.69 \\
\hline & TSP & 6.5 & 3.9 & 6.5 & 0.5 & 0.98 & 0.006 \\
\hline & $\mathrm{MG}$ & -1.5 & -2.1 & -1.4 & 0.2 & 0.75 & 0.09 \\
\hline & Milk & 10.5 & 11.0 & 11.0 & 0.43 & 0.39 & 0.49 \\
\hline \multirow[t]{5}{*}{$\mathrm{Cys}^{3}$} & PDV & 12.1 & 15.8 & 9.9 & 3.8 & 0.67 & 0.28 \\
\hline & Liver & 5.9 & 1.5 & 16.1 & 5.6 & 0.22 & 0.17 \\
\hline & TSP & 18.0 & 17.3 & 21.5 & 4.7 & 0.62 & 0.68 \\
\hline & MG & 0 & 1.6 & -0.8 & 1.6 & 0.68 & 0.33 \\
\hline & Milk & 2.4 & 2.5 & 2.5 & 0.1 & 0.39 & 0.49 \\
\hline \multirow[t]{5}{*}{ Gln } & PDV & 3.3 & 15.1 & 5.2 & 5.5 & 0.79 & 0.11 \\
\hline & Liver & -2.4 & -12.6 & -3.8 & 5.4 & 0.85 & 0.16 \\
\hline & TSP & 0.9 & 2.6 & 5.9 & 4.2 & 0.43 & 0.88 \\
\hline & $\mathrm{MG}$ & -25.0 & -30.4 & -30.4 & 2.8 & 0.15 & 0.44 \\
\hline & Milk & 26.4 & 27.8 & 27.6 & 1.1 & 0.39 & 0.49 \\
\hline \multirow[t]{5}{*}{ Glu } & PDV & 11.3 & 13.1 & 10.1 & 1.1 & 0.44 & 0.09 \\
\hline & Liver $^{4}$ & 28.5 & 29.6 & 30.3 & 1.7 & 0.44 & 0.95 \\
\hline & TSP & 39.8 & 41.7 & 41.2 & 1.6 & 0.57 & 0.57 \\
\hline & MG & -22.8 & -25.1 & -19.6 & 1.3 & 0.08 & 0.05 \\
\hline & Milk & 33.7 & 35.6 & 35.3 & 1.4 & 0.39 & 0.49 \\
\hline \multirow[t]{5}{*}{ Gly } & PDV & 29.6 & 45.2 & 43.2 & 4.7 & 0.08 & 0.13 \\
\hline & Liver $^{4}$ & -39.5 & -55.9 & -53.3 & 3.7 & 0.03 & 0.06 \\
\hline & TSP & -9.8 & -10.7 & -10.6 & 3.3 & 0.87 & 0.91 \\
\hline & MG & 2.3 & 3.4 & -1.7 & 1.7 & 0.11 & 0.18 \\
\hline & Milk & 9.8 & 10.4 & 10.3 & 0.4 & 0.39 & 0.49 \\
\hline \multirow[t]{5}{*}{ His } & PDV & 13.6 & 13.1 & 13.5 & 1.5 & 0.95 & 0.78 \\
\hline & Liver & -4.8 & -6.8 & -5.5 & 1.5 & 0.73 & 0.32 \\
\hline & TSP & 8.8 & 6.3 & 7.4 & 1.0 & 0.37 & 0.20 \\
\hline & MG & -7.9 & -9.1 & -9.0 & 0.4 & 0.08 & 0.28 \\
\hline & Milk & 7.1 & 7.5 & 7.5 & 0.3 & 0.39 & 0.49 \\
\hline $\mathrm{Ile}^{3}$ & PDV & 27.8 & 27.8 & 33.2 & 3.2 & 0.25 & 0.46 \\
\hline & Liver & 4.7 & 4.0 & 3.8 & 2.7 & 0.81 & 0.94 \\
\hline & TSP & 32.5 & 31.8 & 36.9 & 1.6 & 0.10 & 0.20 \\
\hline & $\mathrm{MG}$ & -26.1 & -29.5 & -25.5 & 1.3 & 0.71 & 0.06 \\
\hline & Milk & 18.4 & 19.5 & 19.3 & 0.8 & 0.39 & 0.49 \\
\hline $\mathrm{Leu}^{3}$ & PDV & 48.8 & 54.2 & 53.3 & 6.0 & 0.59 & 0.64 \\
\hline & Liver & 9.5 & 5.0 & 14.9 & 6.1 & 0.52 & 0.31 \\
\hline & TSP & 58.3 & 59.2 & 69.6 & 2.6 & 0.02 & 0.19 \\
\hline & MG & -46.8 & -52.4 & -46.4 & 1.6 & 0.83 & 0.02 \\
\hline & Milk & 30.6 & 32.3 & 32.0 & 1.3 & 0.39 & 0.49 \\
\hline $\operatorname{Lys}^{3}$ & PDV & 34.0 & 32.3 & 35.0 & 3.2 & 0.83 & 0.54 \\
\hline & Liver & 3.9 & 1.6 & 2.4 & 2.1 & 0.60 & 0.50 \\
\hline & TSP & 37.9 & 33.9 & 36.7 & 1.9 & 0.66 & 0.20 \\
\hline & MG & -27.5 & -30.1 & -28.3 & 1.3 & 0.57 & 0.19 \\
\hline & Milk & 23.3 & 24.6 & 24.3 & 1.0 & 0.39 & 0.49 \\
\hline
\end{tabular}


Table 8 (Continued). Effect of graded amounts of ruminally protected Met (RPM) on splanchnic and mammary net fluxes of AA $(\mathrm{mmol} / \mathrm{h})$ in lactating Holstein cows ${ }^{1}$

\begin{tabular}{|c|c|c|c|c|c|c|c|}
\hline \multirow[b]{2}{*}{ Amino acid } & \multirow[b]{2}{*}{ Tissue $^{2}$} & \multicolumn{3}{|c|}{ RPM, g/d } & \multirow[b]{2}{*}{ SEM } & \multicolumn{2}{|c|}{$P$} \\
\hline & & 0 & 36 & 72 & & Linear & Quadratic \\
\hline \multirow[t]{5}{*}{$\mathrm{Met}^{3}$} & PDV & 12.4 & 13.1 & 15.0 & 1.0 & 0.10 & 0.59 \\
\hline & Liver & -3.2 & -3.8 & -4.3 & 1.2 & 0.51 & 0.98 \\
\hline & TSP & 9.1 & 9.3 & 10.7 & 0.9 & 0.29 & 0.60 \\
\hline & MG & -8.5 & -8.7 & -8.8 & 0.5 & 0.66 & 0.98 \\
\hline & Milk & 7.7 & 8.1 & 8.0 & 0.3 & 0.39 & 0.49 \\
\hline \multirow[t]{5}{*}{$\mathrm{Phe}^{3}$} & PDV & 26.8 & 25.2 & 28.7 & 2.2 & 0.52 & 0.31 \\
\hline & Liver & -12.8 & -12.9 & -12.6 & 2.0 & 0.95 & 0.92 \\
\hline & TSP & 14.0 & 12.3 & 16.5 & 0.7 & 0.04 & 0.01 \\
\hline & MG & -12.9 & -13.5 & -13.4 & 0.6 & 0.45 & 0.54 \\
\hline & Milk & 12.2 & 12.8 & 12.7 & 0.5 & 0.39 & 0.49 \\
\hline \multirow[t]{5}{*}{ Pro } & PDV & 20.9 & 24.7 & 17.5 & 5.1 & 0.63 & 0.35 \\
\hline & Liver & -6.6 & -7.6 & -2.2 & 9.3 & 0.86 & 0.53 \\
\hline & TSP & 20.9 & 17.1 & 16.6 & 8.3 & 0.73 & 0.87 \\
\hline & MG & -9.6 & -9.2 & -12.3 & 5.6 & 0.70 & 0.80 \\
\hline & Milk & 35.6 & 37.6 & 37.2 & 1.5 & 0.39 & 0.49 \\
\hline \multirow[t]{5}{*}{ Ser } & PDV & 36.0 & 40.2 & 39.1 & 4.7 & 0.63 & 0.62 \\
\hline & Liver & -24.2 & -29.3 & -27.2 & 3.7 & 0.55 & 0.40 \\
\hline & TSP & 11.8 & 10.9 & 12.6 & 1.8 & 0.75 & 0.57 \\
\hline & MG & -10.4 & -8.7 & -13.8 & 1.9 & 0.17 & 0.18 \\
\hline & Milk & 24.6 & 25.9 & 25.7 & 1.0 & 0.39 & 0.49 \\
\hline \multirow[t]{4}{*}{ Taurine } & PDV & 2.6 & 3.0 & 0.3 & 1.3 & 0.25 & 0.31 \\
\hline & Liver & -2.0 & -2.4 & -2.9 & 1.0 & 0.51 & 0.94 \\
\hline & TSP & 0.5 & 0.6 & -2.4 & 0.8 & 0.04 & 0.17 \\
\hline & MG & 1.2 & 0.6 & 1.4 & 0.5 & 0.72 & 0.30 \\
\hline \multirow[t]{5}{*}{$\mathrm{Thr}^{3}$} & PDV & 23.9 & 24.1 & 26.9 & 2.0 & 0.29 & 0.54 \\
\hline & Liver & -3.7 & -6.9 & -2.6 & 2.0 & 0.70 & 0.14 \\
\hline & TSP & 20.2 & 17.2 & 23.8 & 0.7 & 0.009 & $<0.001$ \\
\hline & MG & -16.7 & -17.2 & -17.0 & 0.8 & 0.77 & 0.76 \\
\hline & Milk & 14.8 & 15.6 & 15.5 & 0.6 & 0.39 & 0.49 \\
\hline \multirow[t]{5}{*}{$\mathrm{Tyr}^{3}$} & PDV & 20.1 & 20.3 & 22.8 & 2.4 & 0.43 & 0.66 \\
\hline & Liver & -7.9 & -7.9 & -8.3 & 2.2 & 0.90 & 0.94 \\
\hline & TSP & 12.2 & 12.4 & 15.8 & 1.2 & 0.08 & 0.30 \\
\hline & MG & -12.0 & -13.2 & -12.6 & 0.7 & 0.46 & 0.30 \\
\hline & Milk & 12.7 & 13.4 & 13.3 & 0.5 & 0.39 & 0.49 \\
\hline \multirow[t]{5}{*}{$\mathrm{Val}^{3}$} & PDV & 33.4 & 38.5 & 35.7 & 5.3 & 0.75 & 0.51 \\
\hline & Liver & 9.3 & 4.0 & 10.9 & 2.5 & 0.66 & 0.07 \\
\hline & TSP & 42.8 & 42.5 & 46.5 & 4.6 & 0.59 & 0.72 \\
\hline & MG & -32.6 & -38.4 & -32.5 & 1.6 & 0.98 & 0.03 \\
\hline & Milk & 23.1 & 24.4 & 24.2 & 0.9 & 0.39 & 0.49 \\
\hline
\end{tabular}

${ }^{1}$ Least squares means with SEM given for $\mathrm{n}=6,6$, and 5 with 0,36 , and $72 \mathrm{~g} / \mathrm{d}$ of RPM, for PDV and Liver data; $\mathrm{n}=6$ for TSP and MG data.

${ }^{2}$ Tissues: $\mathrm{PDV}=$ portal-drained viscera; TSP = total splanchnic tissue; $\mathrm{MG}=$ mammary glands.

${ }^{3}$ Measured on whole blood $(\mathrm{n}=6)$.

${ }^{4}$ Parity $\times$ treatment interaction $(P<0.05)$.

Table 9. Effect of graded amounts of ruminally protected Met (RPM) on arterial concentrations of metabolites and hormones in lactating Holstein cows ${ }^{1}$

\begin{tabular}{|c|c|c|c|c|c|c|}
\hline \multirow[b]{2}{*}{ Item } & \multicolumn{3}{|c|}{ RPM, g/d } & \multirow[b]{2}{*}{ SEM } & \multicolumn{2}{|c|}{$P$} \\
\hline & 0 & 36 & 72 & & Linear & Quadratic \\
\hline \multicolumn{7}{|l|}{ Blood } \\
\hline Ammonia-N (mM) & 0.49 & 0.44 & 0.48 & 0.04 & 0.73 & 0.30 \\
\hline Urea-N (mM) & 9.03 & 8.14 & 8.37 & 0.41 & 0.13 & 0.13 \\
\hline \multicolumn{7}{|l|}{ Plasma } \\
\hline Glucose $(\mathrm{m} M)$ & 3.10 & 3.20 & 3.16 & 0.08 & 0.59 & 0.47 \\
\hline Glucagon (ng/mL) & 0.15 & 0.15 & 0.15 & 0.01 & 0.84 & 0.93 \\
\hline Insulin (ng/mL) & 0.87 & 1.12 & 0.81 & 0.14 & 0.75 & 0.14 \\
\hline
\end{tabular}

\footnotetext{
${ }^{1}$ Least squares means with SEM, $\mathrm{n}=6$.
} 
Table 10. Effect of graded amounts of ruminally protected Met (RPM) on splanchnic and mammary net fluxes of metabolites and hormones in lactating Holstein cows ${ }^{1}$

\begin{tabular}{|c|c|c|c|c|c|c|c|}
\hline \multirow[b]{2}{*}{ Item } & \multirow[b]{2}{*}{ Tissue $^{2}$} & \multicolumn{3}{|c|}{ RPM, g/d } & \multirow[b]{2}{*}{ SEM } & \multicolumn{2}{|c|}{$P$} \\
\hline & & 0 & 36 & 72 & & Linear & Quadratic \\
\hline \multicolumn{8}{|l|}{ Blood } \\
\hline \multirow[t]{3}{*}{ Ammonia-N $(\mathrm{mmol} / \mathrm{h})$} & PDV & 498 & 514 & 459 & 43.1 & 0.52 & 0.47 \\
\hline & Liver & -466 & -484 & -422 & 44.8 & 0.49 & 0.45 \\
\hline & TSP & 33 & 30 & 45 & 15.7 & 0.61 & 0.68 \\
\hline \multirow[t]{3}{*}{ Urea-N (mmol/h) } & PDV & -570 & -607 & -461 & 64.6 & 0.30 & 0.27 \\
\hline & Liver & 930 & 943 & 867 & 114.6 & 0.72 & 0.77 \\
\hline & TSP & 481 & 426 & 459 & 86.3 & 0.86 & 0.69 \\
\hline \multicolumn{8}{|l|}{ Plasma } \\
\hline \multirow[t]{4}{*}{ Glucose (mmol/h) } & PDV & 45 & 58 & -37 & 52.6 & 0.28 & 0.40 \\
\hline & Liver & 561 & 597 & 492 & 106.7 & 0.63 & 0.58 \\
\hline & TSP & 713 & 678 & 541 & 73.1 & 0.15 & 0.59 \\
\hline & MG & -457 & -563 & -482 & 53.0 & 0.21 & 0.19 \\
\hline \multirow[t]{3}{*}{ Glucagon $(\mu \mathrm{g} / \mathrm{h})$} & PDV & 46 & 38 & 48 & 5.2 & 0.77 & 0.19 \\
\hline & Liver & -29 & -14 & -32 & 5.7 & 0.64 & 0.12 \\
\hline & TSP & 18 & 22 & 15 & 5.6 & 0.74 & 0.48 \\
\hline \multirow[t]{3}{*}{ Insulin $(\mu \mathrm{g} / \mathrm{h})$} & PDV & 514 & 478 & 427 & 59.7 & 0.31 & 0.92 \\
\hline & Liver & -315 & -282 & -187 & 56.3 & 0.15 & 0.64 \\
\hline & TSP & 205 & 181 & 235 & 44.4 & 0.65 & 0.49 \\
\hline
\end{tabular}

\footnotetext{
${ }^{1}$ Least squares means with SEM given for $\mathrm{n}=5 ; \mathrm{n}=5,6$ and 5 with 0,36 and $72 \mathrm{~g} / \mathrm{d}$ of RPM, respectively, for PDV and Liver data; $\mathrm{n}=6$ for TSP data.

${ }^{2}$ Tissues: $\mathrm{PDV}=$ portal-drained viscera TSP $=$ total splanchnic tissue MG = mammary glands.
}

2000; Korhonen et al., 2000, 2002; Raggio et al., 2004;) estimated mammary plasma flow to range from 434 to $937 \mathrm{~L} / \mathrm{h}$, with milk production varying from 23 to $48 \mathrm{~kg} / \mathrm{d}$.

\section{Amino Acids}

Supplementation with RPM caused an elevation in arterial concentration of Met. This is in agreement with a previous trial in this laboratory (Berthiaume et al., 2001) and in previously published studies in which Met was ruminally protected (Overton et al., 1996, 1998; Blum et al., 1999) or infused postruminally (Guinard and Rulquin, 1995; Pisulewski et al., 1996; Varvikko et al., 1999). Using lactating dairy cows with rumen and intestinal cannulas, Berthiaume et al. (2001) showed that 73\% of RPM bypassed the rumen, that at least $80 \%$ of this Met disappeared from the small intestine, and that $69 \%$ of Met absorbed in the mesenteric vein was recovered in the portal vein. Therefore, the 2 levels of RPM fed in the present trial would correspond to postruminal supplies of 22 and $44 \mathrm{~g} / \mathrm{d}$ respectively, and should have increased the amount of Met disappearing from the small intestine by 18 and $35 \mathrm{~g} / \mathrm{d}$, and the PDV flux of Met by 12 and $24 \mathrm{~g} / \mathrm{d}$. However, RPM supplementation increased measured net PDV fluxes of Met by 2.5 and $9.3 \mathrm{~g} / \mathrm{d}$, which amount to 20 and $38 \%$ of expected increments. Reasons for such a low recovery of extra Met remain unclear; however, increased oxidation of AA across the PDV has been shown to be related to total supply- arterial plus absorption (Hanigan et al., 2004b). In our study, both arterial and luminal supplies increased with RPM supplementation, which could have resulted in a higher oxidation rate of Met across the PDV, and thus, underestimation of the availability of Met from RPM.

It has been suggested recently that hepatic removal of AA was closely associated with total hepatic influx, both in late lactation and in nonlactating dairy cows (Lobley and Lapierre, 2003; Hanigan et al., 2004a). Such an association was not observed in the current study, despite the fact that arterial and portal concentrations of Met largely increased, thereby increasing total hepatic influx of Met by $47 \%$, from 0 to $72 \mathrm{~g} / \mathrm{d}$ RPM. However, in the studies mentioned earlier (Lobley and Lapierre, 2003; Hanigan et al., 2004a), Met was not the only AA provided. Rather, the total supply of protein was increased by manipulating the diet or through the infusion of AA mixtures, causing an increase in the plasma concentrations of all AA. Perhaps an increase in the concentration of all AA is required to significantly alter hepatic removal of AA. However, studies in which only an analog of Met (2-hydroxy-4[methylthio]-butanoic acid) was infused intravascularly, and only a higher concentration of the L-form of Met was induced (Lobley et al., 2001), hepatic removal of Met almost doubled from 8 to $15 \mathrm{mmol} / \mathrm{h}$. This would indicate that the liver is able to react to changes in the supply of a single AA, contrary to what was observed in the present study. A possible explanation for this apparent contradiction is that this close relationship 
between hepatic influx and hepatic removal of AA is observed only when the increment in Met concentration is under the $\mathrm{L}$-form. Because RPM is an equimolar mixture of the D and L forms, the plasma of RPM-fed cows will contain both the D and L forms (Lobley et al., 2001). The 2 isomers are metabolized differently and therefore may behave differently across the liver.

Overall, the addition of RPM resulted in a numerical, although statistically nonsignificant, increase of the amount of Met delivered to the peripheral tissues (net TSP fluxes) as was shown by others (Bach et al., 2000).

Whole blood Cys and plasma Tau concentrations were also increased by the addition of RPM in agreement with reported data using the same source (Overton et al., 1998) or other sources (Blum et al., 1999) of RPM. Cysteine concentrations reported in this study are higher than usually reported in the literature (Guinard and Rulquin, 1995; Mackle et al., 2000). This may reflect analytical problems associated with Cys determination (Lee et al., 1993). C. Girard and H. Lapierre (Dairy and Swine Research Centre, Lennoxville, QC, Canada, personal communication), using special conditions outlined by Malinow et al. (1989), measured Cys by HPLC in the plasma of lactating dairy cows supplemented with RPM. They observed levels of Cys similar to those measured in whole blood in the present trial.

We observed a linear decrease in whole blood concentrations of Phe, Leu, and Val. Other studies have shown that RPM causes a decrease in plasma levels of Phe (Overton et al., 1996), His (Guinard and Rulquin, 1995), and BCAA (Guinard and Rulquin, 1995; Blum et al., 1999). Results from a previous trial in this laboratory (Berthiaume et al., 2001) showed that the addition of $72 \mathrm{~g} / \mathrm{d}$ of RPM to the diet of midlactation dairy cows elicited a significant decrease in circulating levels of Lys, Phe, Thr, and Val. Therefore, concentrations of BCAA and Phe appear to be consistently decreased with RPM supplementation. Interestingly, in this experiment, the postliver supply of the BCAA, Phe, Tyr, and Thr increased with the addition of RPM. This was unexpected and remains unexplained, although the possible interaction in the metabolism of Met and BCAA through Met transamination pathway has already been demonstrated (Benevenga, 1984). It is particularly interesting to note that following the addition of RPM, circulating concentrations of Met increased although net TSP fluxes of Met were unchanged while circulating concentrations of BCAA and Phe decreased despite an increase of the net TSP fluxes of those EAA. This suggests that RPM triggered a homeorhetic response that may have been mediated through MG in the case of the BCAA, as indicated by the elevation of
BCAA uptake by MG, and through other tissues (e.g., muscle) in the case of Phe. The circulating levels of other EAA were similar to those reported in the literature (Overton et al., 1996; Pisulewski et al., 1996; Vanhatalo et al., 1999) and were not affected by the addition of RPM to the diet. In the case of NEAA, the addition of RPM had a quadratic effect on the circulating concentrations of Ala, Asn, Gln, and Ser. In all cases, concentrations decreased with the addition of $36 \mathrm{~g} / \mathrm{d}$ of RPM and returned to the control level with the addition of $72 \mathrm{~g} / \mathrm{d}$ of RPM. This suggests that as the diet went from a deficit (control) to adequate (36 $\mathrm{g} / \mathrm{d}$ of RPM) and excessive (72 g/d of RPM) Met levels, those $4 \mathrm{AA}$ were used as carbon and nitrogen shuttles, with the body trying to maintain lactation (homeorhesis) while avoiding Met toxicity (homeostasis).

Data presenting PDV, liver, TSP, and MG fluxes of individual AA in lactating dairy cows are very limited, thus explaining our interest in investigating interorgan fluxes. With the exception of Met, Glu, and Gly, net PDV fluxes of individual AA were unaffected by RPM. However, the liver metabolized individual AA to varying degrees. In the case of EAA, we observed no net release or uptake of BCAA and Lys, whereas Met (26\% of PDV flux) and Phe (50\% of PDV flux) were the 2 EAA removed in the largest amount by the liver of cows fed the control diet. The addition of RPM had no effect on Met or other sulfur AA subsequent to absorption, except for an unexpected linear decrease in TSP fluxes of Tau, a product of Met catabolism. However, hepatic-arterial differences for Tau were not different from zero. Although RPM had no effect on the net liver flux or on fractional hepatic extraction of other EAA, net TSP fluxes of the BCAA, Phe, and Thr were all increased with the addition of $72 \mathrm{~g} / \mathrm{d}$ of RPM. To our knowledge this phenomenon has never been reported, and deserves more research.

In the present study, as reported with sheep (Milano et al., 2000) and beef cattle (Lapierre et al., 2000), liver uptake relative to portal release of NEAA was considerably higher than for EAA. Addition of RPM caused a linear increase in liver extraction of Asn and Gly and a linear increase in net TSP fluxes of Ala and Tyr. As determined previously (Bach et al., 2000) with lactating dairy cows, Gly, Ala, and Ser were the 3 AA removed in the greatest quantity by the liver. The fact that these $3 \mathrm{AA}$ are glucogenic and that Gly is involved in the synthesis of bile acids and hippurate could explain why the net TSP flux of Gly was negative. Negative TSP fluxes of Gly have been reported previously with high-producing dairy cows (Bach et al., 2000). The linear increase in TSP flux of Ala is consistent with the absence of an effect of RPM on gluconeogenesis. 
The addition of RPM did affect mammary extraction of Met, which decreased linearly from 38.4 to $27.1 \%$, as observed by others following intragastric infusions of DL-Met (Guinard and Rulquin, 1995; Varvikko et al., 1999). However, the addition of RPM also provoked a linear increase in mammary extraction of the BCAA, His, Phe, and Tyr. This phenomenon was not observed by others, which may be due to the possibility that Lys was deficient in this study and that cows were probably in negative energy balance (Table 1). This data set also allowed us to study the relationship between net TSP fluxes of EAA and milk protein and EAA output. In the control, EAA from group 1 as defined by Fleet and Mepham (1985) were more efficiently captured by the mammary gland and transferred to milk $($ ratio of milk/TSP: His $=0.81$, Met $=0.85$, and Phe $=$ $0.92)$ than group $2 \mathrm{AA},(\mathrm{Ile}=0.57$, Leu $=0.52,=\mathrm{Lys}=$ 0.61 , Thr $=0.73$, and $\mathrm{Val}=0.54)$. This is in agreement with a major catabolism of Met, His, and Phe in the liver (Lapierre et al., 2005).

\section{Metabolites and Hormones}

Nitrogenous Compounds. Arterial or net splanchnic fluxes of ammonia-N and urea-N were not affected by RPM. Arterial concentrations of ammonia-N were similar to those reported by Huntington (1984) and Reynolds et al. (1988) with lactating dairy cows but urea-N concentrations were higher than those reported in previous studies from this laboratory (Berthiaume et al., 2001; Blouin et al., 2002; Raggio et al., 2004). This may be reflective of differences in diet composition and metabolic status of the cows. Portal-drained viscera net fluxes of ammonia-N and urea$\mathrm{N}$ were in agreement with values reported earlier (Blouin et al., 2002; Raggio et al., 2004). However, extraction of PDV ammonia-N by the liver was lower in this trial (93\%) than reported by Reynolds et al. (1988) and Blouin et al. (2002) (>100\%) but similar to hepatic removal of ammonia-N (94\%) reported by De Visser et al. (1997) and Raggio et al. (2004). This resulted in a numerically positive absorption of ammonia-N (36 mmol/h) by the splanchnic tissue. However, hepatic-arterial differences were not different from zero. In the present study, the PDV removed 59\% of the urea-N produced by the liver. This is higher than previously reported (Blouin et al., 2002; Raggio et al., 2004) and, again, could be related to the diet fed in this study. As mentioned previously, posttrial evaluation of the diet with the AminoCow (2004) model indicated that, considering the limited DM intake and the high level of milk production, this diet was marginally deficient in CP and RDP, a situation that should have led to more recycling of $\mathrm{N}$ through urea entry into the gut.
Glucose. The addition of RPM had no effect on plasma concentrations or net fluxes of glucose across the splanchnic tissue and MG. Arterial concentrations and positive net PDV fluxes of glucose were in agreement with values reported by others (Weighart et al., 1986; Casse et al., 1994; Blouin et al., 2002), although again, portal-arterial differences were not different from zero. However, a number of studies have not found a net absorption of glucose through the PDV of lactating cows (De Visser et al., 1997; Reynolds et al., 1988; Berthiaume et al., 2001). Data with growing beef steers (Huntington et al., 1989) and heifers (Reynolds et al., 1991) suggest that dietary factors (amount and source of starch) are responsible for the differences between trials.

Net hepatic glucose production $(2.38 \mathrm{~kg} / \mathrm{d})$ was sufficient to cover mammary glucose requirements (2.3 $\mathrm{kg} / \mathrm{d})$ estimated by dividing milk lactose yield ( $1.61 \mathrm{~kg} /$ d) by 0.7 (Elliot, 1976). Net mammary uptakes and mammary extractions of glucose were in close agreement with those reported in studies where incremental levels of Met were infused intragastrically (Guinard and Rulquin, 1995; Varvikko et al., 1999). In both cases, Met had no effect on glucose metabolism through the MG.

Pancreatic Hormones. Circulating levels of insulin were similar to those reported in the literature (Casse et al., 1994; Guinard and Rulquin, 1995; Pisulewski et al., 1996; Blum et al., 1999). Duodenal infusions of Met had either no effect (Pisulewski et al., 1996) or elicited a quadratic increase (Guinard and Rulquin, 1995) in the circulating levels of insulin. The nonsignificant quadratic increase observed in the present trial would lend support to the latter. Liver, PDV, and TSP fluxes of insulin were slightly higher than fluxes reported with lactating dairy cows (Casse et al., 1994). Addition of RPM had no effect on circulating levels of glucagon, which were similar to those reported in steers fed at a high level of intake (Lapierre et al., 2000) but lower than values reported for dairy cows (Casse et al., 1994). It has been reported that infusion of supraphysiological levels of Met in sheep caused a significant increase in the concentrations of glucagon (Kuhara et al., 1991). This may indicate that the levels of RPM fed in the present trial were in the physiological range for high-producing dairy cows. The liver removed between 44 and $61 \%$ of insulin PDV flux and between 37 and $67 \%$ of glucagon PDV flux, lending support to the idea that the liver has a major impact on peripheral concentrations of pancreatic hormones (Reynolds et al., 1989; Lapierre et al., 2000). In any of the blood vessels sampled, RPM had no effect on insulin to glucagon ratio (data not shown). Although the interaction between parity and treatment was not 
significant, higher circulating levels and fluxes of insulin in primiparous cows (data not shown) indicate the difference in the endocrine status of the two groups of cows and should be kept in mind regarding the interpretation of the data.

\section{CONCLUSIONS}

The addition of incremental doses of RPM resulted in a linear increase in the amount of Met absorbed through the PDV and a numerical increase in the delivery of Met to the peripheral tissues. Consequently, arterial concentrations of Met almost doubled with RPM. The apparent imbalance in the profile of AA supplied, caused by the addition of a larger than required amount of RPM to the diet, had a positive effect on the net TSP flux of other EAA, namely, Ile, Leu, Phe, and Thr, and on the net TSP flux of 2 NEAA, Ala and Tyr. This suggests that the splanchnic tissue acted as a buffer trying to rebalance AA supply to the peripheral tissues, reiterating our argument that it is impossible to define a general rate of AA extraction across the liver. Finally, net uptake of Met by the MG was unaffected by RPM despite a large increase in arterial inflow. This suggests that Met was delivered to other peripheral tissues, thereby confirming that the $\mathrm{MG}$ are more responsive to a demand for milk protein output than to an increase in arterial supply.

\section{ACKNOWLEDGMENTS}

The authors would like to thank David Brown, Lisa Croteau, Martin Demers, Mario Léonard, Sylvie Provencher, and Jocelyne Renaud for sample collection, animal care, and laboratory analyses. The statistical advice of Steve Méthot and the surgical expertise of Marie Babkine are also gratefully acknowledged. Appreciation is extended to Degussa, Agriculture and Agri-Food Canada, and the Natural Science and Engineering Research Council for their financial support.

\section{REFERENCES}

Amino Cow. 1999. The Mepron dairy ration evaluator. Version 2.1. Degussa Corp., Hanau, Germany.

AOAC. 1996. Official Methods of Analysis. 16th ed. Association of Official Analytical Chemists, Arlington, VA.

Bach, A., G. B. Huntington, S. Calsamiglia, and M. D. Stern. 2000. Nitrogen metabolism of early lactation cows fed diets with two different levels of protein and different amino acid profiles. J. Dairy Sci. 83:2585-2595.

Bartels, H., and H. Harms. 1959. Sauerstoffdissoziationskurven des blutes von säugetieren. Pflügers Archiv. 268:S334-365.

Benevenga, N. J. 1984. Evidence for alternative pathways of methionine catabolism. Pages 1-18 in Advances in Nutritional Research. Vol. 6. H. H. Draper, ed. Plenum Press, New York NY.

Benson, J. A., C. K. Reynolds, P. C. Aikman, B. Lupoli, and D. E. Beever. 2002. Effect of abomasal vegetable oil infusion on splanchnic nutrient metabolism in lactating dairy cows. J. Dairy Sci. 85:1804-1814.

Berthiaume, R., P. Dubreuil, M. Stevenson, B. W. McBride, and H. Lapierre. 2001. Intestinal disappearance, mesenteric and portal appearance of amino acids in dairy cows fed ruminally protected methionine. J. Dairy Sci. 84:194-203.

Blouin, J. P., J. F. Bernier, C. K. Reynolds, G. E. Lobley, P. Dubreuil, and H. Lapierre. 2002. Effect of supply of metabolizable protein on splanchnic fluxes of nutrients and hormones in lactating dairy cows. J. Dairy Sci. 85:2618-2630.

Blum, J. W., R. M. Bruckmaier, and F. Jans. 1999. Rumen-protected methionine fed to dairy cows: Bioavailability and effects on plasma amino acid pattern and plasma metabolite and insulin concentrations. J. Dairy Sci. 82:1991-1998.

Broderick, G. A., and J. H. Kang. 1980. Automated simultaneous determination of ammonia and total amino acids in ruminal fluid and in vitro media. J. Dairy Sci. 63:64-75.

Calder, A. G., K. E. Garden, S. E. Anderson, and G. E. Lobley. 1999. Quantitation of blood and plasma amino acids using isotope dilution electron impact gas chromatography / mass spectrometry with $\mathrm{U}_{-}{ }^{13} \mathrm{C}$ amino acids as internal standards. Rapid Commun. Mass Spectrom. 13:2080-2083.

Canadian Council on Animal Care. 1993. Guide to the Care and Use of Experimental Animals. Vol. 1. E. D. Offert, B. M. Cross, and A. A. McWilliam, ed. CCAC, Ottawa, Ontario.

Cant, J. P., E. J. DePeters, and R. L. Baldwin. 1993. Mammary amino acid utilization in dairy cows fed fat and its relationship to milk protein depression. J. Dairy Sci. 76:762-774.

Casse, E. A., H. Rulquin, and G. B. Huntington. 1994. Effect of mesenteric vein infusion of propionate on splanchnic metabolism in primiparous Holstein cows. J. Dairy Sci. 77:3296-3303.

CPM Dairy, Version 1.0. 1998. Department of Animal Sciences, Cornell University, Ithaca, NY.

De Visser, H., H. Valk, A. Klop, J. Van Der Meulen, J. G. M. Bakker, and G. B. Huntington. 1997. Nutrient fluxes in splanchnic tissue of dairy cows: Influence of grass quality. J. Dairy Sci. 80:1666-1673.

Elliot, J. M. 1976. The glucose economy of the lactating dairy cow. Page 59 in Proc. Cornell Nutr. Conf. Feed Mfg. Cornell Univ., Ithaca, NY.

Fleet, I. R., and T. B. Mepham. 1985. Mammary uptake of amino acids and glucose throughout lactation in Friesland sheep. J. Dairy Res. 52:229-237.

Gill, J. L. 1978. Design and analysis of experiments in the animal and medical science. The Iowa State University Press. Ames, IA.

Guinard, J., and H. Rulquin. 1995. Effects of graded amounts of duodenal infusions of methionine on the mammary uptake of major milk precursors in dairy cows. J. Dairy Sci. 78:2196-2207.

Hanigan, M. D., L. A. Crompton, C. K. Reynolds, D. Wray-Cahen, M. A. Lomax, and J. France. 2004a. An integrative model of amino acid metabolism in the liver of the lactating dairy cow. J. Theor. Biol. 228:271-289.

Hanigan, M. D., C. K. Reynolds, D. J. Humphries, B. Lupoli, and J. D. Sutton. 2004b. A model of net amino acid absorption and utilization by the portal-drained viscera of the lactating dairy cow. J. Dairy Sci. 87:4247-4268.

Herbein, J. H., R. J. Aiello, L. I. Eckler, R. E. Pearson, and R. M. Akers. 1985. Glucagon, insulin, growth hormone, and glucose concentrations in blood plasma of lactating dairy cows. J. Dairy Sci. 68:320-325.

Huntington, G. B. 1984. Net absorption of glucose and nitrogenous compounds by lactating Holstein cows. J. Dairy Sci. 67:19191927.

Huntington, G. B., C. K. Reynolds, and B. Stroud. 1989. Techniques for measuring blood flow in splanchnic tissues of cattle. J. Dairy Sci. 72:1583-1595.

Huntington, G. B. 1989. Hepatic urea synthesis and site and rate of urea removal from blood of beef steers fed alfalfa hay or a concentrate diet. Can. J. Anim. Sci. 69:215-223.

Katz, M. L., and E. N. Bergman. 1969. Simultaneous measurements of hepatic and portal venous blood flow in the sheep and dog. Am. J. Physiol. 216:946-952. 
Korhonen, M., A. Vanhatalo, and P. Huhtanen. 2002. Evaluation of isoleucine, leucine and valine as a second limiting amino acid for milk production in dairy cows fed grass silage diets. J. Dairy Sci. 85:1533-1545.

Korhonen, M., A. Vanhatalo, T. Varvikko, and P. Huhtanen. 2000. Responses to graded postruminal doses of histidine in dairy cows fed grass silage diets. J. Dairy Sci. 83:2596-2608.

Krishnamoorthy, U. C., C. J. Sniffen, M. D. Stern, and P. J. Van Soest. 1983. Evaluation of a mathematical model of digesta and in-vitro simulation of rumen proteolysis to estimate the rumen undegraded nitrogen content of feedstuffs. Br. J. Nutr. 50:555-568

Kuhara, T., S. Ikeda, A. Ohneda, and Y. Sasaki. 1991. Effects of intravenous infusion of 17 amino acids on the secretion of $\mathrm{GH}$, glucagon, and insulin in sheep. Am. J. Physiol. 260:E21-E26.

Lapierre, H., J. F. Bernier, P. Dubreuil, C. K. Reynolds, C. Farmer, D. R. Ouellet, and G. E. Lobley. 2000. The effect of feed intake level on splanchnic metabolism in growing beef steers. J. Anim. Sci. 78:1084-1099.

Lapierre, H., R. Berthiaume, G. Raggio, M. C. Thivierge, L. Doepel, D. Pacheco, P. Dubreuil, and G. E. Lobley. 2005. The route of absorbed nitrogen into milk protein. Anim. Sci. 80:11-22.

Lapierre, H., C. Farmer, C. Girard, and P. Brazeau. 1992. Effect of age and intake on growth hormone kinetics in dairy heifers. Domest. Anim. Endocrinol. 9:199-207.

Lee, J., P. M. Harris, B. R. Sinclair, and B. P. Treloar. 1993. Whole body metabolism of cysteine and glutathione and their utilization in the skin of Romney sheep: Consequences for wool growth. J. Agric. Sci. 121:111-124.

Lobley, G. E., and H. Lapierre. 2003. Post-absorptive metabolism of amino acids. Pages 737-753 in Progress in Research on Energy and Protein Metabolism. W.B. Souffrant and C.C. Metges, ed. EAAP Publication No. 109. Wageningen Acad. Press, Wageningen, The Netherlands.

Lobley, G. E., H. Lapierre, and M. Vasquez-Anon. 2001. HMB metabolism in ruminants. Pages $15-24$ in Southwest Nutrition and Management Conference Proc., Univ. Arizona, Tucson.

Mackle, T. R., D. A. Dwyer, K. L. Ingvartsen, P. Y. Chouinard, D. A. Ross, and D. E. Bauman. 2000. Evaluation of whole blood and plasma in the interorgan supply of free amino acids for the mammary gland of lactating dairy cows. J. Dairy Sci. 83:1300-1309.

Malinow, M. R., S. S. Kang, L. M. Taylor, P. W. K. Wong, B. Coull, T. Inahara, D. Mukerjee, G. Sexton, and B. Upson. 1989. Prevalence of hyperhomocyst(e)inemia in patients with peripheral arterial occlusive disease. Circulation 79:1180-1188.

Mepham, T. B. 1982. Amino acid utilization by lactating mammary gland. J. Dairy Sci. 65:287-298.

Mepron Dairy Ration Evaluator. Version 2.1. 1999. Degussa Hüls Corp., Allendale, NJ.

Milano, G. D., A. Hotson-Moore, and G. E. Lobley. 2000. Influence of hepatic ammonia removal on ureagenesis, amino acid utilization and energy metabolism in the ovine liver. Br. J. Nutr. 83:307-315.

National Research Council. 1989. Nutrient Requirements of Dairy Cattle. 6th rev. ed. Natl. Acad. Sci., Washington, DC.

National Research Council. 2001. Nutrient Requirements of Dairy Cattle. 7th rev. ed. Natl. Acad. Sci., Washington, DC.

Oddy, V. H., J. M. Gooden, and E. F. Annison. 1984. Partitioning of nutrients in Merino ewes. I. Contributions of skeletal muscle, the pregnant uterus and the lactating mammary gland to total energy expenditure. Aust. J. Biol. Sci. 37:375-388.

Overton, T., D. LaCount, T. Cicela, and J. Clark. 1996. Evaluation of a ruminally protected methionine product for lactating dairy cows. J. Dairy Sci. 79:631-638.
Overton, T., L. S. Emmert, and J. Clark. 1998. Effects of source of carbohydrate and protein and rumen-protected methionine on performance of cows. J. Dairy Sci. 81:221-228.

Patton, R. A., C. J. Peel, and W. Heimbeck. 1998. Effect of protected methionine (Mepron M85) on milk yield and composition on commercial dairy farms. J. Dairy Sci. 81(Suppl. 1):345. (Abstr.)

Peel, C. J., and R. A. Patton. 1998. Dietary factors associated with production responses to a rumen protected methionine (Mepron M85) on commercial dairy farms. J. Dairy Sci. 81(Suppl. 1):346. (Abstr.)

Pisulewski, P. M., H. Rulquin, J. L. Peyraud, and R. Vérité. 1996. Lactational and systemic responses of dairy cows to postruminal infusions of increasing amounts of methionine. J. Dairy Sci. 79:1781-1791.

Raggio, G., D. Pacheco, R. Berthiaume, G. E. Lobley, D. Pellerin, G. Allard, P. Dubreuil, and H. Lapierre. 2004. Effect of level of metabolizable protein on splanchnic flux of amino acids in lactating dairy cows. J. Dairy Sci. 87:3461-3472.

Reynolds, C. K., G. B. Huntington, H. F. Tyrrell, and P. J. Reynolds. 1988. Net portal-drained visceral and hepatic metabolism of glucose, L-lactate, and nitrogenous compounds in lactating Holstein cows. J. Dairy Sci. 71:1803-1812.

Reynolds, C. K., G. B. Huntington, T. H. Elsasser, H. F. Tyrrell, and P. J. Reynolds. 1989. Net metabolism of hormones by portaldrained viscera and liver of lactating Holstein cows. J. Dairy Sci. 72:1459-1468.

Reynolds, C. K., H. F. Tyrrell, and P. J. Reynolds. 1991. Effects of diet forage-to-concentrate ratio and intake on energy metabolism in growing beef heifers: Net nutrient metabolism by visceral tissues. J. Nutr. 121:1004-1015.

Reynolds, C. K., P. C. Aikman, B. Lupoli, D. J. Humphries, and D. E. Beever. 2003. Splanchnic metabolism of dairy cows during the transition from late gestation through early lactation. J. Dairy Sci. 86:1201-1217.

Rulquin, H., R. Vérité, J. Guinard, and P. M. Pisulewski. 1995. Dairy cows' requirements for amino acids. Pages $143-160$ in Animal Science Research and Development: Moving Toward a New Century. M. Ivan, ed. Can. Soc. Anim. Sci., Ottawa, ON.

SAS Institute. 2000. SAS Statistical Analysis System. Release 8.02. SAS Institute Inc., Cary, NC.

Schwab, C. G. 1995. Rumen protected amino acids - their role in nutrition of high producing ruminants. Pages 161-175 in Animal Science Research and Development: Moving Toward a New Century. M. Ivan, ed. Can. Soc. Anim. Sci., Ottawa, ON, Canada.

Strumia, M. M., A. B. Sampe, and E. D. Hart. 1954. An improved micro hematocrit method. Am. J. Clin. Pathol. 24:1016-1024.

Swaisgood, H. E. 1995. Protein and amino acid composition of bovine milk. Pages 464-472 in Handbook of Milk Composition. R. E. Jensen, ed. Academic Press, San Diego CA.

Vanhatalo, A., P. Huhtanen, V. Toivonen, and T. Varvikko. 1999. Response of dairy cows fed grass silage diets to abomasal infusions of histidine alone or in combinations with methionine and lysine. J. Dairy Sci. 82:2647-2685.

Van Soest, P. J., J. B. Robertson, and B. A. Lewis. 1991. Methods for dietary fiber, neutral detergent fiber, and non-starch polysaccharides in relation to animal nutrition. J. Dairy Sci. 74:3583-3597.

Varvikko, T., A. Vanhatalo, T. Jalava, and P. Huhtanen. 1999. Lactation and metabolic responses to graded abomasal doses of methionine and lysine in cows fed grass silage diets. J. Dairy Sci. 82:2659-2673.

Wieghart, M., R. Slepetis, J. M. Elliot, and D. F. Smith. 1986. Glucose absorption and hepatic gluconeogenesis in dairy cows fed diets varying in forage content. J. Nutr. 116:839-850. 